\title{
A Conceptual Human Resource Strategy Framework for Rural Tour- ism After Covid-19 Pandemic: Case Study in Sukajadi Village, Bogor District, Province of West Java
}

\author{
Yuviani Kusumawardhani ${ }^{1 *}$, Tiurida Lily Anita ${ }^{2}$, Maidar Simanihuruk ${ }^{1}$ \\ ${ }^{1}$ Sekolah Tinggi Pariwisata Bogor, Indonesia \\ ${ }^{2}$ Bina Nusantara University, Indonesia \\ *Corresponding Author: kusumawardhaniyuvi@gmail.com \\ DOI: https://doi.org/10.24922/eot.v8i2.77440
}

\section{Article Info \\ Submitted: \\ August $7^{\text {th }} 2021$. \\ Accepted: \\ September $17^{\text {th }} 2021$. \\ Published: \\ September $30^{\text {th }} 2021$}

\begin{abstract}
The Covid-19 pandemic demands that all industries adapt quickly, and the tourism industry is no exception. Tourism as an industry that contributes significantly to a country's GDP must be able to respond to changes in tourist interest. Tourism village is one of Indonesia's tourism potentials and has a big influence on economic development. However, the level of awareness of village community tourism in Indonesia is still lacking. The stigma that the production process only comes from the agricultural production process is still very much attached. The purpose of the study was to find out how the conceptual framework of the Human Resources (HR) development strategy in the tourist village of Sukajadi, Bogor Regency, West Java, after the Covid-19 pandemic. The research method used is a qualitative approach with Soft System Methodology (SSM) analysis tools with expert respondents who are included in the tourism village stakeholders. This study produces a conceptual framework for the human resource development strategy of Sukajadi Tourism Village, which is integrative and holistic in nature to form an HR management system. Results show that, three strategies for developing human resources in tourist villages were found to increase the capacity of human resources in tourist villages. These strategies include a policy strategy for developing tourism village communities and tourism awareness groups, a strategy for standardizing MSME products, and an approach strategy for tourism awareness groups and institutions.
\end{abstract}

Keywords: Human Resource, Rural Tourism, Human Resource Strategy

\section{INTRODUCTION}

During the COVID-19 pandemic which is pushing the world towards digitalization, the tourism sector must be able to respond quickly to changes in tourist interest. Why is that? Because the tourism sector is seen as one of the industries with the largest growth in economic development in a country (Grigaliunaite, Pileliene, \& Bakanauskas, 2015; Stetic, 2012). UNWTO data in the first quarter of early 2020 showed the number of tourist arrivals decreased drastically by $57 \%$. This is due to the implementation of lockdowns in seve- 
ral countries. Visit data in The Asia Pacific also showed a relative and absolute decline, namely minus 33 million arrivals. Indonesia as a country in the Asia Pacific clearly experienced the same thing with a significant decrease in the number of tourist visits, which was $70.57 \%$ in September 2020 (BPS, 2020). Indonesia needs to take tactical steps to adapt to this situation.

Indonesia is known for its natural potential and various kinds of culture. This shows that Indonesia's tourism potential is very diverse, ranging from nature tourism to cultural tourism. One of the tourism potentials in Indonesia is tourism village. Tourism village is alternative tourism that offers tranquility, education about local culture, and direct interaction with nature and local people and their culture. Saxena et al (2007) said that in today's modern era, the countryside has a function not only for the production of agricultural commodities, but also as a place for recreation, tourism, special food production, consumption, and e-commerce. Lane and Kastenholz (2015) indicate that rural tourism has existed since the end of the nineteenth century in Europe and America, but in the 1970s and 1980s because of the high market pressure for tourist villages, the community, tourism village communities, and the government no longer cared about tourism. protected area or area. The combination of rural and tourism is an effective development step because it has a large impact on the economy and has a high absorption of labor. The same thing is said by (Augustyn, 1998; Flisher \& Felsenstein, 2000) that tourist villages have a great influence on economic income and employment so that the government can restrain population movement from rural to urban areas.

The Empowerment of human resources in tourism development is reflected in the development of a tourist village. However, the empowerment of human resources also requires the awareness of the village community that tourism can provide welfare and increase the income of the village community. Unfortunately, the level of awareness of village community tourism, especially in Indonesia, is still lacking. They still think that the production process only comes from the agricultural production process. Good management is needed between related parties for the realization of a tourist village based on human resource empowerment. Hwang, Stewart, and Ko (2012) said a good partnership between village communities and stakeholders will have a sustainable impact on tourism growth. Effective collective action can increase the solidarity, identity, and empowerment of a village community so as to strengthen the position of the village community in negotiating with outsiders (Jing and Bihu 2017). The United States is revitalizing rural communities with partnerships between universities and rural communities (Grunwell \& Ha 2014). The same thing can be used as an approach to tourism development by revitalizing the village but the rights of villagers are still considered because it can affect the social environment.

Empowerment of Human Resources (HR) is the main key to success in implementing the tourism village concept. However, HR is often seen only as an asset, so that HR cannot contribute optimally. HR is a long-term investment for the organization. HR has an important role in determining the sustainability, effectiveness, and competitiveness of a business (Noe et al., 2006). HR as the driving factor of the system has a critical role so it needs to be managed systematically with management. HR management requires an understanding of the system boundaries regarding the internal and external environment. Why is that? Because organizations and humans enter into an open system that is influenced by the external environment. Likewise, human resources in the development of 
tourist villages involve many parties and are tasked with transforming inputs into outcomes. When the system has been established, the role of HR in the system is to check whether the system is running in accordance with the policy or not and provide feedback in the form of information that will be corrected through corrective action. The systems approach in HR management strategy provides a conceptual framework for integrating all components in the system and integrating HR with the needs of the larger organization. The HR management system that is formed in a tourist village will provide a clear picture of HR to know their respective roles and duties so that policies in realizing a tourist village can be implemented and minimize the obstacles that occur. Dessler (2013) also said that the role of proper HR management can help organizations achieve their goals.

Based on the above background, this research was conducted to find out how the conceptual framework of the Human Resources (HR) development strategy in the Sukajadi tourist village, Bogor Regency, West Java, Indonesia after the Covid-19 pandemic was carried out. The HR strategy model that is formed is integrative and holistic to form the HR management system. This research is innovative because it is able to describe the problems that occur, especially in the role of the main actor driving the system, and empirically also describes the problem of human resources in developing tourist villages. In addition, this research also provides a framework for further research in the future, which is still rare in this study.

\section{LITERATURE REVIEW}

Human Resource Management Strategy

According to Kotler \& Armstrong (2016), human resource management is an integrated and coherent strategic approach to work, development, and human well-

http://ojs.unud.ac.id/index.php/eot being within the organization. On the other hand, Boxall and Purcell (2016) argue that human resource management is a management process that is able to create a highperformance workforce in accordance with the needs of the organization. Often Human Resources (HR) are seen only as "humans" not, as resources, however, more than that, HR are humans who have the knowledge, skills, and energy used in carrying out activities. HR is used as a strategy in achieving organizational goals. HR strategy determines the direction and goals of the organization through its policies and HR Management (HRM) practices which are then integrated with each other's business strategies. Strategy must have two main elements consisting of strategic objectives and plans.

Humans as strategic resources require development in order to become quality resources. Rowley and Jackson (2012) say human resource development is a process carried out to develop the knowledge, skills, and abilities of workers, as well as competencies developed through training and development, organizational learning, leadership management, and knowledge management for the benefit of the community. performance improvement.

According to Jusmaliani (2011) to advance the quality of human resources there are three dimensions that must be considered, namely: 1) Personality Dimension, which involves the ability to maintain integrity, including attitudes, behavior, ethics, and morality, 2) Productivity Dimensions concerning what is produced by humans in terms of more numbers and better quality, and 3) The dimension of creativity concerns a person's ability to think and act creatively, creating something useful for himself and society. Improving the quality of human resources can be manifested in increasing knowledge, skills, dedication, loyalty, discipline, attitude, behavior, awareness, activity, creativity, productivity, 
profession, human relations, accountability, corps spirit, and career. Thus, HR development activities are basically carried out to produce changes in the behavior of the people who take part in the training. Changes in behavior that can be used as indicators of development are the increase in knowledge, expertise, skills, and changes in attitudes and behavior.

\section{Rural Tourism}

Suryawandani et al. (2017) said that a tourist village is part or all of a village area that has tourism potential, products, and activities that can be utilized for tourism development and managed by community groups in the village in a sustainable manner. Community-based tourism is considered as an alternative to sustainable tourism because this type of tourism emphasizes the active involvement of local communities and their control over tourism development in their area (Marinovski, 2016). The transformation of the village as a tourist destination will increase the need for facilities and infrastructure as well as the management of natural resources and human resources. Tourism villages are related to areas that have local wisdom (customs, culture, and potential) which are managed as tourist attractions according to their abilities, which are shown for the social and economic interests of the community (Hermawan, 2017).

\section{METHODS}

\section{Research Location}

The research was conducted in the tourist village of Sukajadi, Bogor Regency, West Java. This village is geographically located to the south of Mount Salak and directly adjacent to the Mount Halimun Salak National Park. This village has natural potential in the form of pine forests, agro-tourism, culinary tourism, and cultural tourism

\section{Sampling Method}

http://ojs.unud.ac.id/index.php/eot
The sampling technique used nonprobability sampling, namely purposive sampling. Purposive sampling was taken based on certain predetermined criteria. Experts play an important role in providing an assessment of the existing problems. The experts used in this study were 5 experts related to, namely (1) the chairman of POKDARWIS; (2) a village official; (3) a representative of the tourism destination development of Bogor Regency; (4) representative of MSME actors; and (5) an academician from university.

\section{Research Model}

The research method used is a qualitative approach with Soft System Methodology (SSM) analysis tools. Data collection is done by preliminary study, observation, literature study, and expert opinion. The soft systems approach is considered a very productive methodology for studying any organized human activity in achieving certain goals (Patel, 1995). So that SSM is very suitable to be implemented as a problem-solving framework specifically designed for situations where the problem is essentially difficult to define (Martin, 2008; Sinn, 1998).

The SSM method has 7 stages (Figure 1), namely: Examine unstructured problems. At this stage, the collection of necessary information related to the HR development strategy, including views and for village development towards a CHSEbased smart tourism village, assumes the parties involved. Primary information is obtained through in-depth discussions with competent experts. Meanwhile, secondary data were obtained from library documents of government and private institutions including research materials. Express the problem situation. The material obtained in the first stage is then used to build a rich picture (real-world map depiction) or also called a representation of the current state. Develop a problem definition related to the 
Table 1. Elements and Definitions of CATWOE

\begin{tabular}{ll}
\hline Element of CATWOE & Description \\
\hline Customer & Who benefits from goal activities? \\
Actor & Who carries out the activities? \\
Wransformation & What has to change for input to be output? \\
Owner & What perspective makes a system meaningful? \\
Environment & Who can stop activities? \\
\hline
\end{tabular}

problem situation. This section is to formulate the root definition, which is a short sentence that states "a system does $\mathrm{P}$ by means of Q to achieve R". The root definition is then stated in the CATWOE mnemonic as shown in Table 1.

Build a conceptual model based on the root definition above for each defined element, then build the conceptual model needed to achieve the ideal goal. This model identifies a system of human activities resulting from the expression of problem situations in a rich picture and presents the relationship between activities. This conceptual model is an adaptive process because there is feedback between the modeling process and the results of the expression of the problem situation. All elements contained in the CATWOE are included in the conceptual model.

Comparing the conceptual model with the problem situation. Conceptual models are compared to the real world to highlight possible changes in the real world. Each party involved provides perceptions and assessments of the activities being modeled, to determine what should be done, maintained, improved or reviewed. The initial draft of the conceptual model was designed by researchers who were then asked for corrections, input, and clarification to each expert as a resource person for this research. A comparison model is formulated covering the activities offered, the reality or real-world conditions that occur and recommendations for follow-up. This model is refined and will be a recommendation for changes.

Establish appropriate and desirable changes. The purpose of this stage is to identify and search for the desired changes systemically and feasible. Changes can occur in terms of structures, procedures or people's attitudes.

Take corrective action on the problem. At this stage, recommendations for changes will appear to be implemented. It will show the right system for making changes whose activities can become "real world".

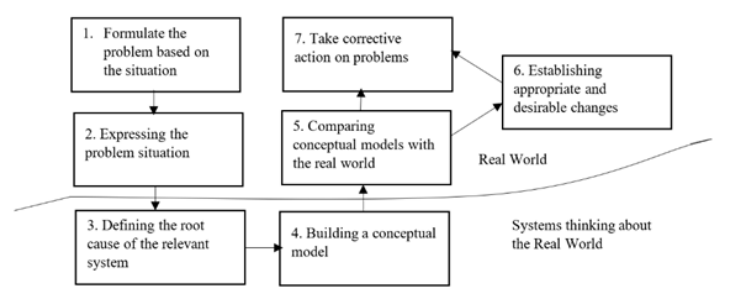

Figure 2. Research Framework Using Soft System Methodology (SSM) Approach

\section{RESULTS AND DISCUSSION}

Based on the steps used in the SSM approach, the following is an explanation of the results and discussion obtained from each of the studied Steps.

\section{Unstructured Problems}

The main problem in developing a tourist village is the human resource factor. The human resource factor referred to in the context of a tourism village is the potential of each individual involved in the process of developing a tourism villa- 
ge as human capital that can be developed to transform inputs into outputs or tourism products. Some of the problems that occur in the human resource factor of tourism village development that has been observed in this study are: The improvement and development of human resources are still low because the government is not yet fully aware that to build a tourist village, strong and characterful human resources are needed. Lack of understanding and knowledge management about the concept of tourism village, especially in adapting to the new normal era, how to apply Clean, Health, Safety, and Environmental Sustainability (CHSE) in tourist villages, creating village tourism products, cultivation, innovation, and the use of technology as a means promotion. Lack of awareness and participation of village communities and related stakeholders to integrate into tourism villages so that the level of welfare and income from the village tourism sector is still low. The productivity of the village as a tourist village is not optimal, due to the lack of human resource knowledge regarding the concept of a tourist village. Low creativity and innovation because people have not used technology as a component in developing tourist villages. The skills of rural communities in developing tourism products and processing food into culinary products are still low, besides that business actors are still running themselves, not yet integrated directly with tourist villages because there is no awareness that their products can be used as tourism products. The intensity of the training is not continuous so that the village community does not focus on the concept of developing a tourist village, in addition to the inconsistency of outside parties in providing training that is based only on personal and group interests. Meanwhile, training is needed for rural communities to improve the quality of tourism village human resources. Sihite \& Nugroho (2018) have a view that HR must organizational activity because HR is the planner, actor, and determinant of the realization of organizational goals.

According to Setiawan (2016), the role of human resources is the key to success in achieving performance, such as in the tourism industry, where companies have direct, intangible relationships with consumers who are very dependent on the ability of individual employees to generate interest and create pleasure and comfort for employees. consumers. Pajriah (2018) also said that the presence of human resources has an important role in tourism development. The importance of HR factors in the tourism sector is the same as other industries that are especially service-based that HR is a key factor in realizing successful performance (Evans, Campbell, \& Stonehouse, 2003).

Based on the various issues described above, the role of stakeholders (stakeholders) has a major role in encouraging human resource development because they are interrelated with one another. This explanation will be described in the form of a tabulated analysis of the hierarchy of problems and the roles of relevant stakeholders in the human resource development problem of Sukajadi Tourism Village (Table 2).

Tourism village actors where tourism as one of the leading sectors need to be supported by their skills and abilities to carry out their respective roles. In addition, commitment, coordination, and synchronization are needed in the development of tourist villages in which all sub-systems of tourist villages are integrated with each other.

\section{Constraints Mapping}

The situation of HR problems faced in the development of tourist villages is depicted in a rich picture with various perspectives that focus on structure, processes, relationships, conflicts, and uncertainty, as well as revealing problems, values that are

$$
\text { e-ISSN 2407-392X. p-ISSN 2541-0857 }
$$


Table 2. Analysis of the Problem Hierarchy

\begin{tabular}{|c|c|c|c|}
\hline Level & Involved Parties & Focus Issue & Characteristic \\
\hline Directive & $\begin{array}{l}\text { Local government } \\
\text { Village head } \\
\text { Ministry of Tourism }\end{array}$ & $\begin{array}{l}\text { HR development policies } \\
\text { in Tourism Villages } \\
\text { Tourism Village develop- } \\
\text { ment policy } \\
\text { Direction and Supervision } \\
\text { Security and Conflict } \\
\text { Social, Political, and } \\
\text { Cultural }\end{array}$ & $\begin{array}{l}\text { Strategic Planning } \\
\text { Tourism Village De- } \\
\text { velopment Policy } \\
\text { Investment and Fi- } \\
\text { nance }\end{array}$ \\
\hline Strategic & $\begin{array}{l}\text { Universities } \\
\text { SME's actors } \\
\text { Bogor Regency } \\
\text { Tourism and Culture } \\
\text { Departement } \\
\text { Tourism awareness } \\
\text { group (Pokdarwis) }\end{array}$ & $\begin{array}{l}\text { Planners and Implement- } \\
\text { ers of the Tourism Village } \\
\text { Development Program } \\
\text { HR Empowerment } \\
\text { Coordination between } \\
\text { Tourism Village actors } \\
\text { Knowledge management }\end{array}$ & $\begin{array}{l}\text { Managerial } \\
\text { Organizing } \\
\text { Monitoring and } \\
\text { Evaluation }\end{array}$ \\
\hline Tactical & $\begin{array}{l}\text { Pokdarwis } \\
\text { Accommodation } \\
\text { owner } \\
\text { SME's actor } \\
\text { Homestay Owner } \\
\text { Universities }\end{array}$ & $\begin{array}{l}\text { Assistance for tourism } \\
\text { village actors } \\
\text { Organizing community } \\
\text { groups } \\
\text { HR capacity development } \\
\text { Village community em- } \\
\text { powerment }\end{array}$ & $\begin{array}{l}\text { Technical operations } \\
\text { Tourist area } \\
\text { Partnership }\end{array}$ \\
\hline Operational & $\begin{array}{l}\text { Rural Community } \\
\text { SME actors } \\
\text { Tourist village group } \\
\text { Universities }\end{array}$ & $\begin{array}{l}\text { Productivity of tourism } \\
\text { village development } \\
\text { Productivity of tourist vil- } \\
\text { lage human resources } \\
\text { Self-development and } \\
\text { skills }\end{array}$ & Tourist area \\
\hline
\end{tabular}

believed and visualized through symbols that has been developed, the problem map (Figure 2).

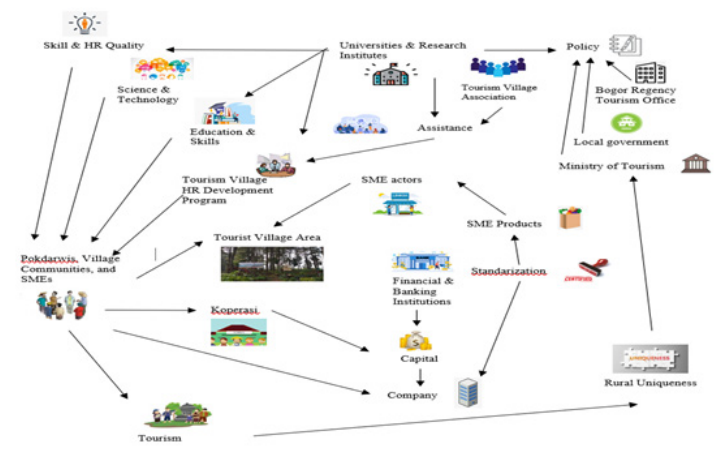

Figure 2. Rich Picture of Constraints

Based on the rich picture mapping regarding human resource development includes the ability and quality of human resources, science, and technology, education, and skills as well as the involvement of stakeholders who play a role in it. Government policies after the Covid-19 pandemic can be both a challenge and a threat to the human resources of the Sukajadi tourist village. Support from various parties is needed to develop human resources for tourism village actors, especially SMEs, Tourism Awareness Groups (Pokdarwis), and village communities. If not handled properly, Indonesian tourism will experien- 
ce a setback.

\section{Root Definition}

Human resource development in the tourism industry is currently facing global challenges that require solutions by breaking through the boundaries of countries, regions, and continents. One solution that needs to be taken is to increase the competence of human resources owned by a country including Indonesia through improving the quality of appropriate education and training (Setiawan, 2016). This is what is being faced by Indonesia to rise again to increase tourist attraction and interest after the Covid-19 pandemic. The process of the HR development system was built using CATWOE analysis (table 3 ).

The system carries out HR development activities for Tourism Villages (P) through the implementation of various HR quality improvement programs on target with the participation of all relevant parties (Q) to improve the quality of HR in a sustainable manner in an effort to revive the tourism industry after Covid-19 (R).

\section{Conceptual Model}

Based on the root definition, a conceptual model was developed to identify the activities needed to develop HR. This conceptual model is a model that has an adaptive process, in which there are interactions that occur between actors and feedback between the process and the actors in it (figure 3).

\section{Comparison of Models with Real World}

After the conceptual model is built, the next step is to compare the conceptual model with the real world which gives results about what needs to be maintained, improved, and created something new. The recommendations needed at this stage are self-development and skills training, comparative studies of tourist villages as direct learning references, creating tourist villa- ges, tourist village assistants and sustainable research. More clearly and details are in table 4.

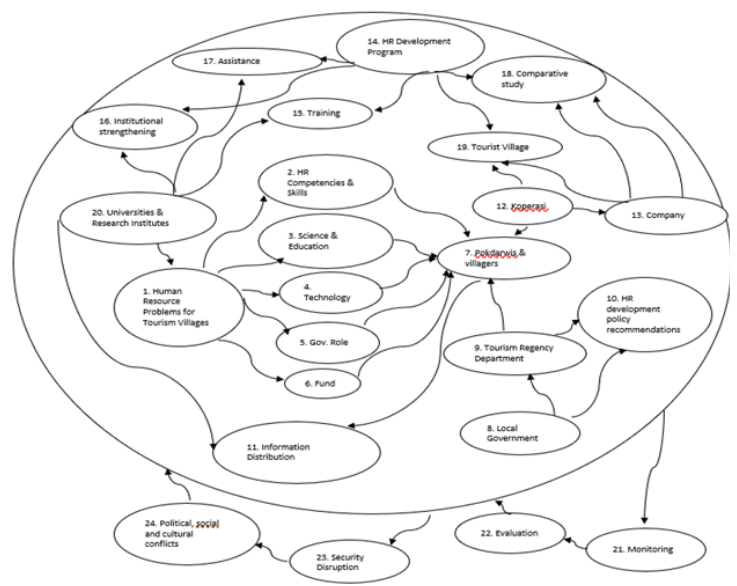

Figure 3. Conceptual Model of Tourism Village HR Development Strategy

\section{Planning of change}

The main goal of developing a tourist village is to revive interest in tourism in Indonesia after the Covid-19 pandemic. Besides that, it also improves the regional economy and improves the welfare of MSME actors and tourism village communities. So that tourist villages can become the most desirable tourist destinations and provide a direct economic impact for the community of tourist villages after the Covid-19 pandemic, tourism village actors must know how to manage post-pandemic tourist villages through their local uniqueness. Tourist village actors also need to master several skills that can support the development of a village into a tourist village. Efforts that need to be made include improving the quality of tourist village human resources and mastery of knowledge and technology because it is currently entering the era of digitalization.

Based on Dewi, Fandeli, and Baiquni (2013) that communities in developing areas should be encouraged to identify their own goals and direct tourism development to improve the fulfillment of local community needs. The development of tourist 
Table 3. CATWOE Analysis

\begin{tabular}{|c|c|c|}
\hline & Description & Definition Result \\
\hline $\mathrm{C}$ & Customer & Pokdarwis, Village Community, Village Head, SME's actors \\
\hline A & Actor & $\begin{array}{l}\text { Universities, Research Institutes, tourist village groups, and local } \\
\text { governments }\end{array}$ \\
\hline $\mathrm{T}$ & Transformation & $\begin{array}{l}\text { The creation of the formulation of a tourism village HR develop- } \\
\text { ment strategy with skills training programs, community empow- } \\
\text { erment, research, and policy formulation. }\end{array}$ \\
\hline W & World view & $\begin{array}{l}\text { The creation of government policies and knowledge for all stake- } \\
\text { holders who are involved together to have a responsibility in } \\
\text { planning, implementing, controlling, and improving the human } \\
\text { resource capacity of tourist villages. }\end{array}$ \\
\hline $\mathrm{O}$ & Owner & Department of Tourism and Local Government \\
\hline $\mathrm{E}$ & Environment & $\begin{array}{l}\text { Limitation HR development program } \\
\text { Commitment and awareness of Tourism Village HR is still low } \\
\text { Lack of role of local government in supporting human resource } \\
\text { development in tourist villages }\end{array}$ \\
\hline
\end{tabular}

villages has a positive contribution to the life and economic welfare of rural communities. It is hoped that through the development of tourist villages, economic equality at the regional level will be achieved, in accordance with the goals of sustainable tourism development. Tourism products in tourist villages are the result of integrating village potentials that have local uniqueness and village local wisdom activities such as nature tourism, culture, and community crafts.

Tourism village human resources must master tourism village marketing technology so that they can utilize technology as a management medium that facilitates the management of the tourist village itself. The program to improve the quality of human resources should be the main focus of various parties in tourist villages in West Java and all tourist villages in Indonesia so that tourist villages have quality human resources and are able to be competitive. There is a need for collaboration between universities, the private sector, and the government as a tactical step to design and implement HR development policies through an approach to empowering local communities.

\section{Improvement Action}

The design strategy needs to be formulated and implemented thoroughly, including evaluation and monitoring during the implementation process. Strategy formulation provides a map that shows all the dynamics that develop over time. Based on Figure 4, the tourism village HR development strategy is formulated, the first regarding tourism village HR development policies which are revealed to be programmed through local governments and related agencies that will support improving the quality of tourist village human resources, such as tourism village management skills after the Covid 19 pandemic. Second, standardization of SME products. Pujiyono, Setyowati, and Idris (2018) argue that common problems that occur in SMEs include weak capital structure and funding sources, availability and sustainability of raw materials, limited mastery of technology, weak organization, and business management, and lack of quantity and quality of human resources. In the era of increasingly fierce modern global competition, the main cau- 
Table 4. Comparison of Conceptual Models and Real World

\begin{tabular}{ll}
\hline Activities & Condition of Real World \\
\hline & \\
Competency and & Facilities and infrastructure to facilitate \\
skill develop- & human resource development are still \\
ment training & limited
\end{tabular}

Approach with institutional strengthening

Comparative studies as direct learning media

Cultural Events (Traditional Events)

Intensive mentoring

Supporting Personnel

Continuous research

\section{Comparative studies have not been} conducted.

Institutions appear not to be well organized, the division of tasks is not clear, and tourism awareness and commitment are low.

Cultural events are held situationally and are not routinely performed. Public awareness to create and bring out the local uniqueness of the village is still low.

Mentoring staff is limited and the commitment of facilitators is still low.

Assistance staff so far have come from universities that have the obligation to carry out community service activities.

Universities, the Ministry of Tourism, and other research institutions have conducted research on the development of tourist villages, analysis of village potential, and the like. Meanwhile, studies on human resource development strategies for tourist villages are still limited.
Recommendation

Procurement of facilities and infrastructure that supports HR development training as well as collaborating with Universities, Tourism Village communities, and SME's actors

Institutional strengthening approaches need to be performed with assistance from Universities and Tourism Village Associations and facilitated to develop Tourism Villages.

It is necessary to conduct comparative studies with other Tourism Villages in order to become learning materials that provide insight, knowledge, and motivation for the Village. The role of the Regional Government to coordinate and cooperate with each other in this comparative study program is also important for the smooth implementation of the program.

Situational and cultural events held not routinely performed. Public awareness to create and bring out the local uniqueness of the village is still low.

The addition of the number of assistants who specifically handle tourism is needed from the Tourism Office, Universities, and Tourism Village Associations. The competence of the companion is also an important thing to note, in addition to the number, of course, the ability and commitment of the companion is also crucial for the development of human resources in the Tourism Village.

Local governments should consider recruiting special assistants who have technical skills, holding a minimum of a Diploma in charge of providing assistance during the work program so that it is right on target.

Studies on the development of human resources in tourist villages to improve the quality of human resources in tourist villages need to be carried out continuously, so that rural communities are able to adapt to current technological developments. This is done to improve people's welfare, regional income, and boost the country's economy. 
ses of difficulties faced by SME entrepreneurs in various regions are limited access to information and dynamic market opportunities, capital and marketing strategies, innovation, and technical human resources. This is what lies behind the need for standardization of SME products in tourist villages so that products from local SMEs can be directly integrated into tourist villages. SME actors need to improve their knowledge and skills to standardize products, so that product standardization socialization is the right program for tourism village SME actors at this time. Third, approach to Pokdarwis and Institutions. An approach to tourism village actors who have an important role in the development of tourist villages needs to be done so that tourism village human resource development programs can be implemented on target.

The approach is carried out by research institutes, universities, and the Ministry of Tourism and given to tourism village communities and pokdarwis. The approach can be done through training, such as tourism awareness training, then gradually given training that has more value for the community, for example, postpandemic tourism village management training based on Clean, Health, Hygiene, and Environmental Sustainability (CHSE), promotion techniques based on digital marketing, and the preparation of tour packages, so that tourist villages are ready to receive post-pandemic tourist arrivals. As for the companions, it is necessary to develop coaching, mentoring, counseling, and training. Why does it need to be developed? Because so that their skills in coaching, mentoring, counseling and training will increase in assisting village communities and pokdarwis.

This study was designed to build a conceptual framework for the Human Resource (HR) development strategy of the Sukajadi tourist village, Bogor Regency, West Java after the Covid-19 pandemic.

http://ojs.unud.ac.id/index.php/eot
This study contributes to the local government in determining human resource development policies for tourist villages after the Covid-19 pandemic so that the tourism industry can make an economic recovery. The conceptual framework of the HR strategy of the tourist village that is built is integrative and holistic to form a human resource management system. Figure 4 summarizes the results of this study, namely the conceptual framework of tourism village $H R$ development strategies.

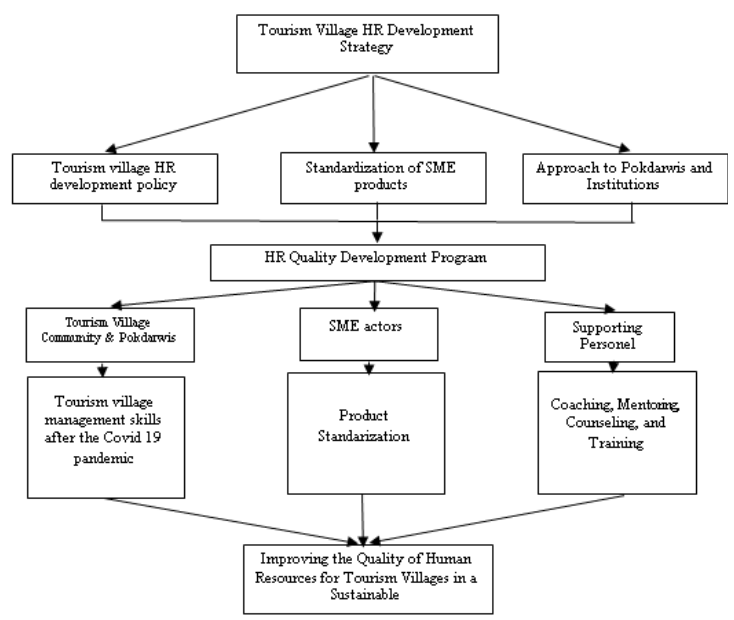

Figure 4. Tourism Village HR development strategy

Through the studies that have been carried out, three strategies for developing human resources in tourist villages were found to increase the capacity of human resources in tourist villages. These strategies include policy strategies for developing tourism village communities and tourism awareness groups, standardization strategies for MSME products, and approaches to tourism awareness groups and institutions. Thus, there are several programs that are recommended to improve the quality of tourism village human resources including post-pandemic tourism village management skills, standardization of MSME products, coaching, mentoring, counseling and training. This program is expected to improve the human resource capacity of 
tourist villages effectively and on target. The results of the study also emphasize the approach to training programs provided to relevant stakeholders.

The literature states that training is very important as one of the organizational strategies to improve human resource capabilities, both competences, and skills. Organizational performance depends on HR performance, therefore Human Capital plays an important role in organizational productivity. To increase organizational productivity, training is highly recommended (Govand Anwar, 2021).

Tourist villages can be an alternative for post-pandemic tourists other than because of their characteristics that are deemed appropriate to the post-covid-19 situation which imposes restrictions on the number of tourists each time they arrive. However, several things need to be considered for tourist villages in Indonesia. Based on data in the 2019 Travel and Tourism Competitiveness Index (TTCI) report, several Indonesian TTCI indicators show scores below the average indicator scores of countries in the Asia-Pacific region, these indicators include indicators of the business environment, health and hygiene, ICT Readiness, environment sustainability, ground, and port infrastructure, and tourist service infrastructure. As for the human resource and labor market indicators, Indonesia has a score equal to the average indicator score of countries in the Asia Pacific. Based on TTCI (2019) the same thing was found in this study, where issues regarding the business environment, health and hygiene, ICT readiness, environment sustainability, and tourist service infrastructure have not been implemented properly in tourist villages, especially in the tourist village of Sukajadi. These indicators point to the ability of human resources in managing all of these indicators so that in addition to the infrastructure that needs to be built by the government, aspects of human resources also need to be improved both in terms of capabilities and skills so that they can produce competitive tourism human resources. Rogers (2012) argues that strategic HR management is the process of developing, implementing, and evaluating HR strategies to support the main strategy.

Based on Rodríguez-Antón \& Alonso-Almeida (2020) Spain has set several strategies for the recovery of the tourism sector in the country in the face of the post-Covid-19 pandemic. These strategies include creating conditions for safe tourist destinations and protecting health. In addition, the Spanish government has also implemented three policies as tactical steps in the recovery of the tourism sector including, a policy to support companies in the tourism sector agreed by the European Commission, a policy of providing incentives to the tourism sector initiated by the Spanish government, and a policy to reduce transmission in the tourism sector. tourism sector agreed by each region in the country of Spain. This illustrates that other countries are trying to take recovery actions for the tourism sector, especially by prioritizing the principles of Clean, Health, Safety, and Environmental Sustainability where HR is the main driving factor.

The managerial implication of this study is to provide skills-building training to village communities and tourism-aware groups such as digital-based tourism village management training, training on the application of CHSE in tourist attractions, homestays, and in the food production process originating from MSMEs. Then, educate MSME actors with knowledge of MSME product standardization by providing food product standardization materials which are then certified with Certification Agencies such as BPOM and MUI to obtain BPOM and halal certificates. Furthermore, providing assistance to the programs mentioned above through coaching, mentoring, counseling, and training. 
The limitation of this study is the difficulty of digging for valid information to find out the real problem. This happens because the informants are still distracted by personal interests, not public interests. In addition, resource persons with certain positions they have often maintain their reputations so that it seems that there are no significant problems when in fact many obstacles are found when determining tourism village HR development policies.

\section{CONCLUSION}

This study finding the fact that stakeholders have an important role as a driving factor for improving the quality of human resources in tourist villages. Therefore, to synchronize the roles of each stakeholder, strategic actions are needed for tourism village actors. The tourism village HR development strategy through the soft system methodology (SSM) approach can contribute to the government in formulating tourism village HR development policies, especially in its efforts to revive tourism after the COVID-19 pandemic. The soft system methodology approach can provide a clear and detailed description of the problems that occur so that the conceptual model design of tourism village HR development strategies can be formulated.

The involvement of the government, the private sector, universities, and research institutions is very important in several programs that are recommended to improve the quality of human resources in tourist villages. There are three groups that are the target of this program, namely (1) the village community and Pokdarwis; (2) MSME actors; and (3) tourist village assistants. Quality human capital is a long-term investment because it invests in intellect. Intellectuality is an important part in the development of an area that can improve the economy and welfare of the community, especially in tourist villages.

http://ojs.unud.ac.id/index.php/eot

\section{ACKNOWLEDGEMENT}

The researcher would like to thank all stakeholders who are willing to be respondents in this study so that this research can be completed properly and researchers can contribute their thoughts in designing the conceptual framework of the human resource development strategy of Sukajadi Tourism Village.

\section{REFERENCES}

Augustyn, M., \& Ho, S. K. (1998). Service Quality and Tourism On behalf of: Travel and Tourism Research Association can be found at: Journal of Travel Research Additional services and information for. Journal of Travel Research Citations: What Is. https://doi. org/10.1177/004728759803700110

Dessler, Garry. 2013. Human Resource Management - Thirteenth Edition. New Jersey: Prentice Hall.

Dewi, M. H. U., Fandeli, C., \& Baiquni, M. 2013. Pengembangan Desa Wisata Berbasis Masyarakat Lokal Di Desa Wisata Jatihluwih Tabanan, Bali. Kawistara,3(2): 117-226.

Evans, Nigel, David Campbell \& George Stonehouse. 2003. Strategic Management for Travel and Tourism. Oxford: Butterworth-Heinemann

Febriyani, N., Suryawardani, B., Prodi, D., Pemasaran, M., Terapan, F. I., \& Email, U. T. (2020). Pengaruh Brand Personality Terhadap Minat Menginap Di Hotel Utc Bandung Tahun 2020 the Effect of Brand Personality on Intention of Staying At the Utc Hotel Bandung 2020. 6(2), 2792-2799.

Govand Anwar, N. N. A. (2021). The Impact of Human Resource Practice on Organizational Performance. International Journal of Engineering, 
Business and Management (IJEBM), 5(01), 35-47. https://doi.org/https:// dx.doi.org/10.22161/ijebm.5.1 Article

Hwang, D., Stewart, W., \& Ko, D.-W. (2012). Community Behavior and Sustainable Rural Tourism Development ENVISION-An inclusive approach to assessing integrative scenarios and visions for protected area management View project place-based conservation: perspectives from the social sciences View project. Article in Journal of Travel Research. https:// doi.org/10.1177/0047287511410350

Jusmaliani M.E. (2011). Pengelolaan Sumber Daya Insani. Bumi Aksara.

Kotler dan Gary Amstrong. (2016). Dasardasar Pemasaran.Jilid 1, Edisi Kesembilan.Jakarta: Erlangga. p125

Lane, B., \& Kastenholz, E. (2015). Journal of Sustainable Tourism Rural tourism: the evolution of practice and research approaches-towards a new generation concept? https://doi.org/10.1080/0966 9582.2015.1083997

Martin, E. 2008. Aplikasi metodologi sistem lunak untuk pengelolaan kawasan hutan rawan konflik: kasus hutan penelitian Benakat, Sumatera Selatan. [Disertasi]. Bogor (ID): Institut Pertanian Bogor.

Noe, R. A, Hollenbeck, J. R., Gerhart, B. \& Wright, P. M. (2006). Human Resources Management: Gaining ACompetitive Advantage.5th Ed. New York: McGraw-Hill/Irwin.

Patel, N. V. 1995. Application of soft systems methodology to the real-world process of teaching and learning. International Journal of Educational Management, 9(1), 13-23.

Pujiono, A., Setyawati, R., \& Idris, I. (2018). Strategi Pengembangan
Umkm Halal Di Jawa Tengah Dalam Menghadapi Persaingan Global. Indonesia Journal of Halal, 1(1), 1. https:// doi.org/10.14710/halal.v1i1.3109

Rodríguez-Antón, J. M., \& Alonso-Almeida, M. D. M. (2020). COVID-19 impacts and recovery strategies: The case of the hospitality industry in Spain. Sustainability (Switzerland), 12(20), 1-17. https://doi.org/10.3390/ su12208599

Roger, S. Pressman, Ph.D. 2012. Rekayasa Perangkat Lunak (Pendekatan Praktisi) Edisi 7 : Buku 1. Yogyakarta (ID): Andi.

Rowley, C., Bae, J., Horak, S., \& BacouelJentjens, S. (2017). The International Journal of Human Resource Management Distinctiveness of human resource management in the Asia $\mathrm{Pa}$ cific region: typologies and levels. The International Journal of Human Resource Management, 28(10), 13931408. https://doi.org/10.1080/095851 92.2016.1189151

Saxena, G., Clark, G., Oliver, T., \& Ilbery, B. (n.d.). Conceptualising Integrated Rural Tourism.

Setiawan, I. R. (2016). Pengembangan Sumber Daya Manusia di Bidang Pariwisata: Perspektif Potensi Wisata Daerah Berkembang. Jurnal Penelitian Manajemen Terapan, 1(1), 23-35. https://journal.stieken.ac.id/index. php/penataran/article/view/301

Sihite, J., \& Nugroho, A. (2018). Exploring the Indonesian Tourism Destination via Indonesia.Travel @indtravel. 52(Ictgtd), 29-32. https://doi. org/10.2991/ictgtd-18.2018.4

Sinn, J. S. (1998). A comparison of interactive planning and soft systems methodology: enhancing the complementarist position. Systemic Practice and

$$
\text { e-ISSN 2407-392X. p-ISSN 2541-0857 }
$$


Action Research, 11 (4), 435-453.

host.v2i1.51

Suryawardani, I. G. A. O., \& Wiranatha, A. World Economic Forum. 2019. Travel and S. (2017). Digital Marketing in Promoting Events and Festivities. a Case Tourism Competitiveness Index Reof Sanur Village Festival. Journal of port. Diunduh 20 November 2019, Business on Hospitality and Tourism, from World Tourism Organization 2(1), 159. https://doi.org/10.22334/jbWebsite: www.wto.org 